Professor of Education in the University College of the Gold Coast. Professor Lewis points out that a university training is no substitute for practical experience and the lessons to be drawn from it, but rather is a preparation, fitting the students to learn the lessons of working experience. Training in the University can also be valuable in giving to the Community Development worker an understanding of the diversity of officers and organizations with whom he will have to work-the hierarchy of the civil service and the local authorities on the one hand, and the people with their own traditions and outlook on the other. In addition, pre-service training in the University should include a study of the history and practice of mass education and community development. He suggests, therefore, that a course of preservice training might comprise the following subjects:

I. The organization and machinery of government with special teference to the working of the civil service and local authorities.

2. An introduction to the methods of anthropological and sociological studies.

3. Techniques of language study in the field.

4. History and methods of mass education and community development.

There are advantages in such a course being taken in the University rather than in a government department: the student would receive guidance in analysis and criticism, leading to a shrewder assessment of facts and trends than is always possible in the atmosphere of the day-to-day task; in the University the exchange of views can be more informal and the university teacher is likely to benefit by having to consider his principles alongside the practical experience of the field worker.

\title{
Development of Local Government in the Colonies
}

A CONFerence was held at Queens' College, Cambridge, England, from 22 August to 2 September 1955 under the auspices of the Royal Institute of Public Administration, with Sir John Wrigley, K.B.E., C.B. as Chairman. The Conference divided into six Study Groups who, during the first week, studied the following aspects of the subject: I. Constitutional and Political Factors in the Development of Local Government; II. Relations of Local Authorities with the Central Government and with Traditional Authorities; III. Financial Resources of Local Authorities; IV. Problems of Representation; V. Internal Organization and Management; VI. Recruitment and Training of Staff. The Reports of these Groups were circulated to all members of the Conference and were discussed in plenary sessions on 31 August and I and 2 September. The Reports, as amended in the plenary sessions, have been published by the Royal Institute of Public Administration (Haldane House, 7 6a New Cavendish Street, London, W. I) together with a general summary of the Conference by the Chairman and a list of the participants (who included officers from British oversea territories, from the British Colonial Office, special consultants on Local Government, observers from Belgium, France, Jordan, United States). Also included in the published Report is a list of courses in Public Administration held in the United Kingdom and in the oversea territories and an appendix giving details of the Financial Resources of Local Authorities in the various territories.

\section{Le Blason de Dakar}

Depurs des années se posait la question de l'adoption d'un blason symbolisant la ville de Dakar. Une vingtaine de projets furent soumis à la Commission désignée pour les examiner et proposer à la Municipalité celui qu'elle estimerait pouvoir être retenu. Aucun d'entre eux ne donnant pleinement satisfaction, la Commission décida de retenir le meilleur d'entre eux 
en empruntant toutefois des éléments à d'autres projets: le prix fut de ce fait partagé entre plusieurs gagnants du concours. Partant de ces données et de ces critiques et pensant au centenaire de Dakar à célébrer en 1957, la Société des Amis de l'IF $A N$ ouvrit, en 1959, un concours doté de prix à l'effet d'établir un blason de la ville.

La description héraldique du projet final, qui fut approuvé par le Conseil Municipal de Dakar en sa séance du 7 février 1956 , est la suivante:

' D'or aux deux chevrons de sinople chaussé d'azur, chargé en chef d'un écusson de gueules au phare d'argent rayonnant d'or de huit pièces, l'azur chargé en pointe de deux pirogues affrontées de sable à la voile d'argent, l'écu timbré d'une couronne murale à trois tours, soutenu par deux branches de tamarinier de sinople.'

En voici la signification: le triangle d'or (jaune) symbolise la presqu'île du Cap Vert dont il rappelle la forme et dont la couleur indique que le sable la recouvre en grande partie. Le phare sur fond de gueules (rouge) est celui des Mamelles, allumé en I 864 et donc l'une des premières constructions importantes de la presqu'île, figurant déjà sur les précédents projets de blason de la ville et rappelant en outre le rôle de Dakar en A.O.F. Les huit rayons d'or (jaunes) symbolisent les huit territoires composant la Fédération. Les deux chevrons symbolisent les deux Mamelles, seul relief caractéristique de la presqu'île et la couleur sinople (verte) le fait que les Mamelles marquent le Cap Vert. Les chevrons, emblèmes de seconde classe, indiquent la modestie du relief (100 m. environ au-dessus du niveau de la mer pour la grande Mamelle).

Les deux côtés azur (bleus) symbolisent la mer, qui entoure la presqu'île à l'Est et à l'Ouest et les pirogues de sable (noires) à voile d'argent (blanche) la communauté léboue, fondatrice de la république théocratique du Cap Vert vers 1795 et 'maîtresse de la terre'. Les deux branches de tamarinier (dakhar en wolof) de sinople (vertes) rappellent l'une des étymologies du nom de la ville (l'autre est deu'raw: le refuge). La couronne aux tours crénelées est celle qui symbolise les villes dans le monde entier.

(Raymond Mauny, Notes Africaines, Juillet 1956)

\section{Oversea Service}

A SERIES of short residential courses for men and women intending to work abroad-in Africa or elsewhere-is organized by Oversea Service, a recent venture originally sponsored by the British Council of Churches and the Conference of British Missionary Societies. The courses are designed to give some idea of the social and cultural background, the economic and occupational structure, and the pattern of government of oversea territories. Each course is confined to one broad region and is further adapted, so far as possible, to suit the particular destinations and occupations of the students accepted. Courses last six or seven days and, after an introductory session at the Imperial Institute, London, are held at Moor Park College, Farnham, Surrey; there are twenty vacancies for each course and the courses are organized for almost all levels of business and government and professional employment. The emphasis is on 'real-life' rather than academic questions and there is ample opportunity for discussion, no topics being barred; factual information, through films, books, and pamphlets, is available. Speakers and guests at each course are specialists in some specific subject-history, administration, industry, race relations-and, generally, have first-hand experience of the territory being studied. Nationals of the countries studied are specially invited. In addition to the courses, Oversea Service provides a personal introduction service to experienced friends abroad, keeps in touch with students who have gone overseas and organizes 'refresher courses' for those returning to Britain on leave. Lists of forthcoming courses, programmes, and other information can be obtained from the General Secretary, 2 Eaton Gate, London (Sloane 96 I I) or Moor Park College, Farnham, Surrey (Farnham 4878). 